\title{
The anomalous wet 2020 southeast Brazil austral summer: Characterization and possible mechanisms
}

\author{
Fernanda CERQUEIRA VASCONCELLOS* and Juan NERES DE SOUZA
}

Departamento de Meteorologia, Instituto de Geociências, Universidade Federal do Rio de Janeiro, Rua Athos da Silveira Ramos, 274, Bloco G, Cidade Universitária, Ilha do Fundão, Rio de Janeiro, Brasil, CEP: 21941-916.

*Corresponding author; email: fernandavasconcellos@igeo.ufrj.br

Received: June 1, 2020; accepted: October 8, 2020

\begin{abstract}
RESUMEN
Se analizan las anomalías del verano austral húmedo de 2020 en el sudeste de Brasil (SEB) y se investigan sus posibles mecanismos. En los años previos a 2020 se registraron veranos secos en el SEB; no obstante, el verano de 2020 fue el más lluvioso desde 1991. Un tren de ondas iniciado en el océano Índico con dirección al océano Pacífico, más un tren de ondas del norte tropical (con forma de U) y otro del Pacífico ecuatorial occidental (similar al patrón Pacífico-América del Sur), contribuyeron a una circulación anticiclónica anómala en altos niveles hacia el sur de Sudamérica. Este tren de ondas combinado continuó su trayectoria como circulación ciclónica anómala sobre el sur de Brasil y el estado de Sao Paulo, y como circulación anticiclónica hacia el norte, acentuando/inhibiendo la convección sobre el SEB. Por otra parte, el patrón del Modo Anular del Sur (SAM, por sus siglas en inglés) se encontraba en fase positiva y se detectó la presencia de anomalías negativas en la temperatura superficial del mar (SST) cerca del SEB y Argentina, lo cual contribuyó a la configuración del fenómeno sobre el continente. Comparaciones entre el verano austral de 2019 (seco) y el de 2020 para establecer sus principales diferencias muestran que no hubo una divergencia anómala en altos niveles sobre el océano Pacífico en 2019 que haya desencadenado un tren de ondas de esta región al Pacífico. Los dos trenes de ondas procedentes del Pacífico se combinaron como circulación anticiclónica anómala sobre el Pacífico sudoccidental, cerca de la costa de Sudamérica. El SAM fue neutral en 2019; sin embargo, hubo anomalías positivas de la SST cerca del SEB, el sur de Brasil y la costa de Argentina. La SST del Atlántico sur y los trenes de ondas generaron una circulación anticiclónica anómala sobre el sur de Brasil y ciclónica hacia el norte, en contraposición con la configuración de 2020.
\end{abstract}

\begin{abstract}
This paper analyzed the anomalous rainy austral summer of 2020 over the southeastern region of Brazil (SEB), investigating its possible mechanisms. The SEB experienced dry summers in the years before 2020; however, the austral summer of 2020 in this region was the wettest since 1991. A wave train starting from the Indian Ocean to the Pacific Ocean, plus a wave train from the tropical north (U-shape), and another from the western equatorial Pacific (PSA-like) contributed to an anomalous anticyclonic circulation at high levels southward South America. This merged wave train continued its path with an anomalous cyclonic circulation over the southern region of Brazil and the state of Sao Paulo, and anticyclonic northward, enhancing (inhibiting) convection over SEB (southern Brazil). Besides, the Southern Annular Mode (SAM) pattern was in a positive phase, and there were negative sea surface temperature (SST) anomalies near SEB and Argentina, contributing for the configuration over the continent. Comparisons of the main differences between the austral summer of 2019 (dry) and the summer of 2020 show there was no anomalous divergence at high levels over the Indian Ocean in 2019, triggering a wave train from this region to the Pacific. The two wave trains from the Pacific merged in an anomalous anticyclonic circulation over the southeastern Pacific, near the South American coast. The SAM pattern was neutral in 2019; however, there were positive SST anomalies
\end{abstract}


near SEB, southern Brazil and Argentina coastal. The South Atlantic SST and the wave trains generated an anticyclonic anomalous circulation over the southern region of Brazil and cyclonic northward, in opposition to the 2020 configuration.

Keywords: southeastern Brazil, wavetrain, Atlantic SST, Southern Annular Mode.

\section{Introduction}

South America is affected by teleconnections, both east-west and south-north, which have an impact on the continental climate (Cavalcanti and Ambrizzi, 2009). However, the influences of these patterns are different over the continent, and they are not clear in some areas, especially over regions of transition between tropics and extra-tropics. Southeastern Brazil (SEB), which includes the states of Sao Paulo, Rio de Janeiro, Minas Gerais, and Espirito Santo, is one of these regions, being cut by the Tropic of Capricorn to the north of Sao Paulo state. SEB is the most populated region of Brazil, concentrating $42.1 \%$ of the country's population (IBGE, 2011), and also has the highest gross domestic product of the country (IPEA, 2020). This region is affected by synoptic phenomena such as frontal systems and the South Atlantic Convergence Zone (SACZ) during the austral summer, which can produce intense precipitation with floods and landslides near the coastal regions (Vasconcellos and Cavalcanti, 2010). The climate variability modes can impact the occurrence and intensity of these main summer precipitation systems.

Pacific sea surface temperature (SST) anomalies impact the South American climate on different scales. These anomalies can, for example, trigger wave trains from the Pacific, generating anomalous circulations at high level over the continent and consequently inducing convection (e.g., Cunningham and Cavalcanti, 2006; Vasconcellos and Cavalcanti, 2010; Coelho et al., 2016a; Bernardino et al., 2018). Carvalho et al. (2004) found a relationship between El Niño-Southern Oscillation (ENSO) and SACZ, in which there is more occurrence of oceanic SACZ during El Niño years (warmer SST over Niño 3.4 region), whereas in La Niña (colder SST over Niño 3.4 region) and neutral years, the continental SACZ would be more frequent. Particularly about SEB, several studies have suggested that impacts of ENSO over this region are different, depending on the area, time of year, phase, and type of ENSO (e.g., Tedeschi et al., 2013, 2016).

SST anomalies in the South Atlantic also influence the climate in South America, including SEB. Studies have shown that negative SST anomalies over the subtropical South Atlantic, near SEB coast, enhance the SACZ (Doyle and Barros, 2002; Bombardi et al., 2014a, b; Jorgetti et al., 2014). Doyle and Barros (2002) showed that negative SST anomalies in the subtropical South Atlantic during the midsummer favor the SACZ activity. Analyzing the period from November to March, Bombardi et al. (2014a) showed that negative SST anomalies over the tropics are associated with the increase of cyclogenesis in the ocean near SEB, as well as the migration of extratropical cyclones further north. However, their tropical SST results include the SEB coast. Thus, these studies have suggested that negative SST anomalies near SEB would lead to an increase in precipitation over this region during the rainy season.

The Southern Annular Mode (SAM) is the leading mode of extratropical variability in the Southern Hemisphere, characterized by north-south seesaws of atmospheric masses between high latitudes and parts of the mid-latitudes (Thompson and Wallace, 2000). Some studies indicate that SAM has impacts in the South American climate (Carvalho et al., 2005; Gillett et al., 2006; Vasconcellos and Cavalcanti, 2010; Rosso et al., 2018; Vasconcellos et al., 2019). Rosso et al. (2018) found that frequency, persistence, and total precipitation in SACZ events are higher in the positive SAM phase, compared to the negative phase. Vasconcellos et al. (2019) studied the month-bymonth impacts of SAM phases on precipitation and air temperature in South America (in years of neutral ENSO). Their results showed that SAM has different impacts depending on the month and the phase of the pattern. For precipitation, the authors revealed that the impacts in SEB are irregular. However, for January-March, the positive (negative) SAM promotes rainy (dry) months over the northern parts of SEB. 
Although some studies indicate the influence of low-frequency modes on SEB climate, the predictability of climate precipitation over this region has proven to be difficult due to the lack of knowledge on the combined effects of climate variability modes on large-scale circulations, which impact precipitation variability over the area (Koster et al., 2000; Nobre et al., 2006). Therefore, the advance of knowledge regarding the mechanisms of precipitation variability might provide the basis for better climate predictability, particularly in the warm and rainy seasons of SEB. Due to its importance on economy, population and low climate predictability, an increase on the learning of climate variability over this region is essential.

SEB has been experiencing consecutive drought years, including the extreme drought of the 2014 austral summer (e.g., Coelho et al., 2016a, b). However, unlike past years, the austral summer of 2020 was unusually rainy. The object of this paper is to characterize SEB precipitation during this season and to investigate possible causes for this anomalous pattern, analyzing the circulation and the influence of variability modes. With the aim of improving the knowledge on the causes of wet anomalies on the 2020 austral summer over SEB, this paper will:

- Diagnose the observed austral summer (January-March) precipitation conditions over SEB.

- Investigate regional mechanisms and possible oceanic and atmospheric teleconnection patterns associated with the wetter 2020 austral summer over the SEB.

- Compare the SST and atmospheric circulation patterns of the 2020 austral summer (rainy) with 2019 (dry).

This paper is outlined as follows. Section 2 introduces the datasets and describes the methods used to characterize the 2019 and 2020 austral summers over SEB and investigate possible causes of these anomalous seasons. Section 3 puts the rainy 2020 austral summer over SEB in an historical context. Section 4 discusses the potential mechanisms associated with the wet 2020 austral summer over SEB. Section 5 shows a comparison of the 2019 (dry) and the 2020 (rainy) austral summers. Summary and conclusions are presented in section 6 .

\section{Dataset and methods}

Monthly outputs of the Global Precipitation Climatology Project (GPCP) have been used in this paper. The GPCP product combines sun-synchronous low-orbit satellite microwave data, geosynchronous-orbit satellite infrared data, and observations from rain gauges, after quality control to produce precipitation estimates. The product has $2.5^{\circ} \times 2.5^{\circ}$ resolution (Adler et al., 2003). The advantage of using GPCP is its global coverage, including oceanic areas. Furthermore, Muza et al. (2009) have shown that GPCP has a satisfactory correspondence with gridded precipitation from stations (Liebmann and Allured, 2005) in areas over tropical and subtropical Brazil.

The Extended Reconstructed Sea Surface Temperature (ERSST) V5 product from the National Oceanic and Atmospheric Administration (NOAA) has been adopted for SST-related analysis. The ERSST uses the new International Comprehensive Ocean-Atmosphere Dataset (ICOADS) release 3.0 SST, which comes from Argo floats above $5 \mathrm{~m}$ and Hadley Centre Ice-SST v. 2 (HadISST2) ice concentration. This dataset has improved SST spatial and temporal variability by: (1) reducing spatial filtering in training the reconstruction functions Empirical Orthogonal Teleconnections (EOTs), (2) removing high-latitude damping in EOTs, and (3) adding 10 more EOTs in the Arctic. The ERSSTv5 also uses unadjusted first guess instead of adjusted first guess. More information about this dataset can be found in Huang et al. (2017).

The monthly outputs of ERA5 Reanalysis were used to compute the circulation and divergences. ERA5 is the fifth generation of atmospheric reanalysis from the European Centre for Medium-Range Weather Forecasts (ECMWF), replacing ERA-Interim, with a higher spatial and temporal resolution. This reanalysis provides estimates of a large number of atmospheric, terrestrial, and oceanic variables. The data covers the entire globe with $0.25^{\circ} \times 0.25^{\circ}$ horizontal resolution, or approximately $30 \mathrm{~km}$, using 137 levels from the surface up to a height of $80 \mathrm{~km}$. The data assimilation system was also renewed, and a large number of historical observations (satellite or in situ) were assimilated. More details about this reanalysis can be found in Hersbach et al. (2020).

This study evaluated the 2019 and 2020 austral summer seasons (JFM mean) over SEB area. The 
analysis is presented through computations of anomalies relative to the climatologic period from 1981 to 2020. To validate the GPCP dataset, the time series was compared to the precipitation products from the Centro de Previsão de Tempo e Estudos Climáticos/ Instituto Nacional de Pesquisas Espaciais (CPTEC/ INPE), available at: http://clima1.cptec.inpe.br/evolu$\mathrm{cao} / \mathrm{pt}$. Results had a good agreement when compared to the time series displayed at the site (not shown). We also compared monthly precipitation anomalies maps (January, February, and March 2019 and 2020) from GPCP to the precipitation products from CPTEC/INPE (available at http://clima1.cptec.inpe.br/monitoramentobrasil/pt). The GPCP and CPTEC/INPE precipitation maps have, in general, a good correspondence, including over SEB (not shown). After these validations of the GPCP dataset, a map of the austral summer 2020 anomalous precipitation over Brazil $\left(40^{\circ} \mathrm{S}-5^{\circ} \mathrm{N}, 75^{\circ}-30^{\circ} \mathrm{W}\right)$ was created to analyze the spatial distribution of anomalies.

Maps of geopotential height anomalies at 700 $\mathrm{hPa}$ and SST for austral summer 2020 were examined with the goal of identifying possible influences of teleconnection patterns. High-level circulation analyses were evaluated through velocity potential anomalies, divergent wind anomalies, and wind anomalies streamlines at $200 \mathrm{hPa}$. The SAM index was also obtained from the Climate Prediction Center (CPC/NOAA) (available at: https://www.cpc.ncep. noaa.gov/products/precip/Cwlink/daily_ao_index/ aao/monthly.aao.index.b79.current.ascii.table).

In order to complement SST results over the Pacific, the Oceanic Niño Index (ONI) was obtained from CPC/NOAA (available at: https://origin.cpc.ncep. noaa.gov/products/analysis_monitoring/ensostuff/ ONI_v5.php). This index is a 3 -month running mean of ERSST v. 5 SST anomalies in the Niño 3.4 region $\left(5^{\circ} \mathrm{N}-5^{\circ} \mathrm{S}-170^{\circ}-120^{\circ} \mathrm{W}\right)$, based on centered 30 -year base periods updated every five years.

The subtropical South Atlantic was further analyzed through time series (1981-2020) of austral summer anomalous SST averaged over the area located between $30^{\circ}-60^{\circ} \mathrm{W}$ and $20^{\circ}-45^{\circ} \mathrm{S}$ and a correlation map between austral summer SST averaged over the subtropical South Atlantic (same area as above) and precipitation (1981-2020). Both series were detrended. Student's t-test (Wilks, 2006) was applied to the correlation map to determine regions in which the composite variables have a confidence level of $90 \%$.

To complement the results found for the 2020 austral summer (rainy), we also created the above-mentioned maps (except for the correlation map) for the 2019 austral summer (dry), with the aim of comparing both summers. Additionally, the ONI index was also obtained for 2019.

\section{The rainy 2020 austral summer over SEB in a historical context}

Figure 1a displays a temporal series of austral summer precipitation anomalies, averaged over SEB. A change of pattern between the 2020 summer and previous years is noteworthy. An anomaly of $1.6 \mathrm{~mm}$ day $^{-1}$ was recorded in the 2020 austral summer over $\mathrm{SEB}$, in opposition to $-1.6 \mathrm{~mm} \mathrm{day}^{-1}$ in the 2019 summer. Since 2011 this region had not displayed above-normal summer precipitation, and 2020 was the wettest summer since 1991 . The precipitation pattern changed from December 2019 (dry) to January 2020 and the following months (rainy) (not shown). The driest summer occurred in 2014, causing severe impacts in water availability for public consumption, hydropower generation, and agriculture within the region (Coelho et al., 2016a, b). The 2020 austral summer presented positive precipitation anomalies over almost all SEB (Fig. 1b), with higher values over the state of Minas Gerais and the division between the states of Rio de Janeiro and Espirito Santo. These positive anomalies extended into the Atlantic Ocean in a NW-SE direction, a similar configuration to oceanic SACZ (Carvalho et al., 2004). This precipitation pattern could indicate a higher frequency and/or longer persistence of this system. The state of Sao Paulo was an exception in SEB, showing negative precipitation anomalies. The different behaviors of precipitation anomalies within SEB confirm that the impacts of low-scale modes are not similar across SEB. The state of Sao Paulo had a similar behavior than the southern region of Brazil in the 2020 austral summer. SEB and southern Brazil (including Sao Paulo) displayed a dipole pattern of precipitation anomalies. The dipolar pattern has also been addressed by previous works (e.g., Cunningham and Cavalcanti, 2006; Vasconcellos and Cavalcanti, 2010; Jorgetti et al., 2014; Bernardino et al., 2018; 


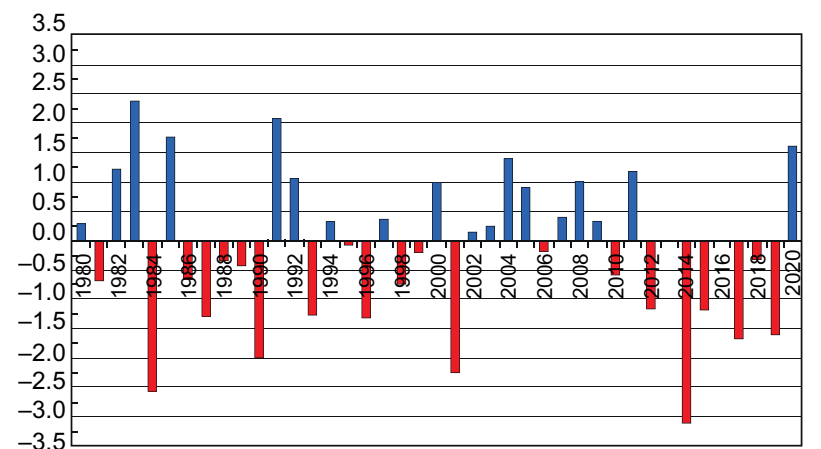

(a)

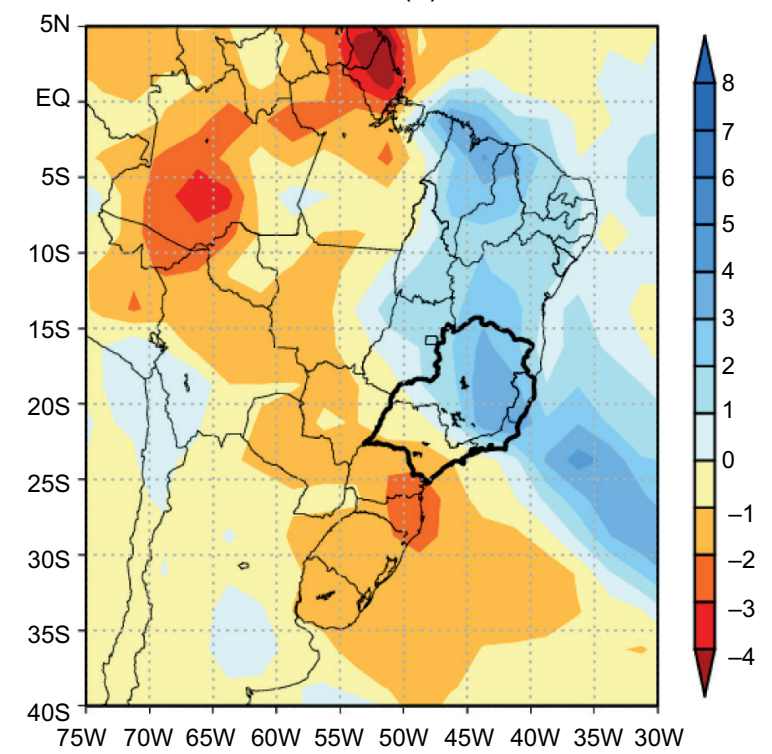

(b)

Fig. 1. Austral summer precipitation anomalies $\left(\mathrm{mm} \mathrm{day}^{-1}\right)$ : (a) 1981-2020 time series area averaged over SEB, and (b) 2020, with the thick black contour enclosing the area of SEB. Data source: Global Precipitation Climatology Project.

Silva et al. 2020). Silva et al. (2020), for example, associated Sao Paulo and southern Brazil with a similar dipole, in opposition to southeastern Brazil, which experienced a positive phase of the Pacific Decadal Oscillation.

\section{Teleconnections, circulation and mechanisms}

Previous works indicate the influence of the SAM over South America (e.g., Carvalho et al., 2005; Gillett et al., 2006; Vasconcellos and Cavalcanti, 2010; Vasconcellos et al., 2019). Figure 2a shows a spatial pattern associated with the positive SAM phase (0.5 index [JFM mean]) in the 2020 austral summer, i.e., negative (positive) geopotential height anomalies over high (middle) latitudes. These results are in accordance with Vasconcellos et al. (2019) regarding the presence of wetter summers over the northern part of SEB in the positive SAM phases. According to Rosso et al. (2018), the positive SAM phase is related with higher frequency, persistence, and total precipitation of SACZ events, which is in agreement with the positive precipitation anomalies over SEB displayed in Figure 1. The influence of lower frequency modes, like PDO, could also be related to this dipole (Silva et al., 2020). It is noteworthy that, despite positive geopotential height anomalies at midlatitudes, related to the positive SAM phase, there was a negative anomaly over the South Atlantic, reaching the coast of SEB. This could be related to wave trains started at the Pacific and Indian oceans, as indicated by alternations of geopotential height anomalies presented in Figure 2a.

There were positive SST anomalies over most of the central and western equatorial Pacific (Fig. 3a), and the ONI index confirms the El Niño phase (Table I). Positive SST anomalies are also shown over the tropical Indian Ocean (Fig. 3a).

The Atlantic Ocean also influences the South American climate (Fig. 4). The correlation map between SST over subtropical South Atlantic and precipitation showed that SST is negatively correlated with rainfall over SEB, northward of Sao Paulo State.

Table I. 2020 austral summer CPC/NOAA indices: Oceanic Niño Index (ONI)*, and SAM index**.

\begin{tabular}{lccc}
\hline \multicolumn{3}{c}{ January-March } \\
\hline ONI & 0.6 \\
\hline & January & February & March \\
\hline SAM & -0.23 & 0.28 & 1.43 \\
\hline
\end{tabular}

*https://origin.cpc.ncep.noaa.gov/products/analysis monitoring/ensostuff/ONI_v5.php

**https://www.cpc.ncep.noaa.gov/products/precip/ Cwlink/daily_ao_index/aao/monthly.aao.index.b79. current.ascii.table

Values above $0.5^{\circ} \mathrm{C}$ are given in red. 


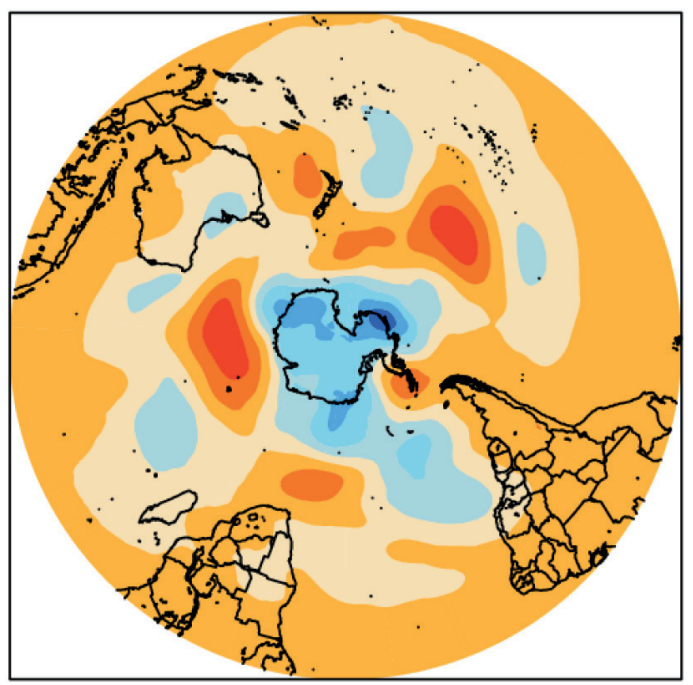

(a)

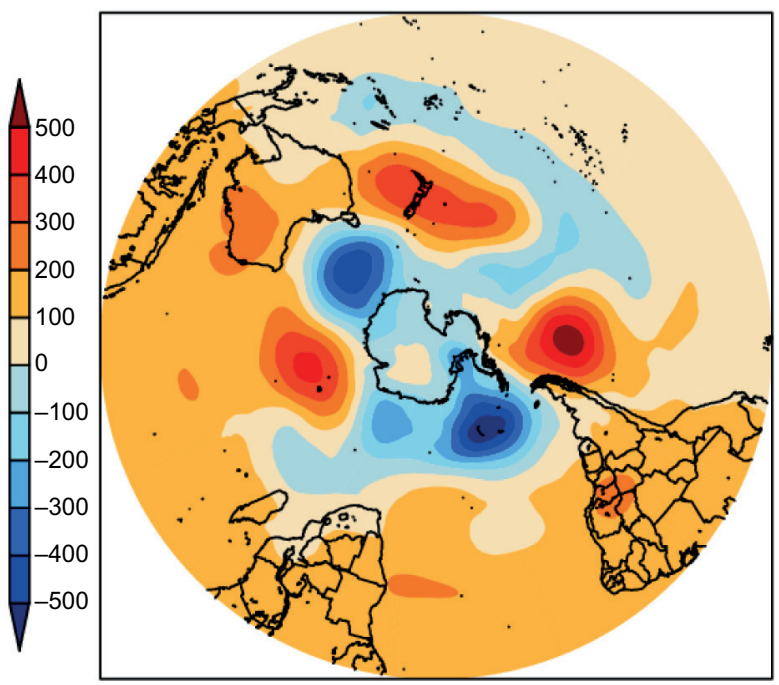

(b)

Fig. 2. Geopotential height anomalies at $700 \mathrm{hPa}$ (mgp): (a) 2020 austral summer, and (b) 2019 austral summer. Data source: ERA5.

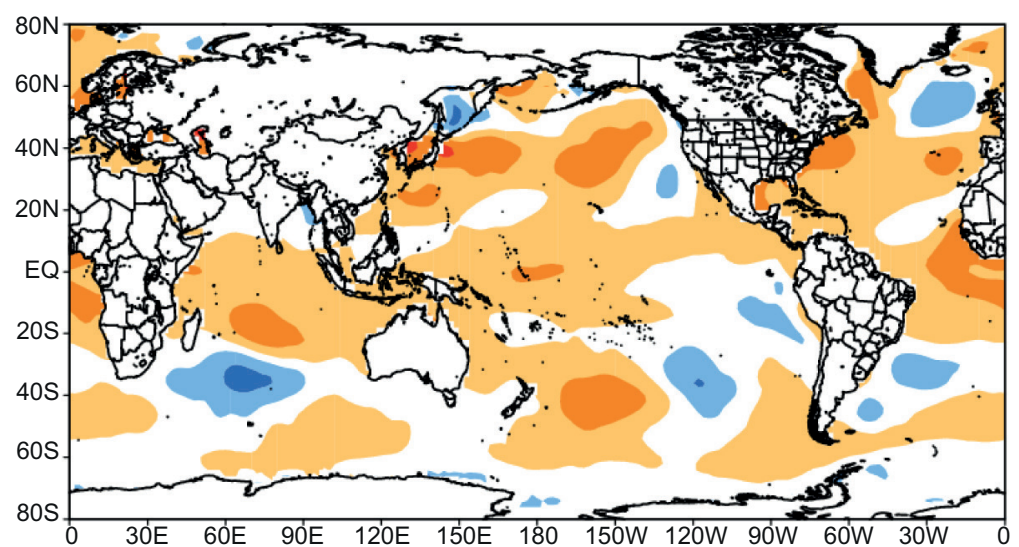

(a)

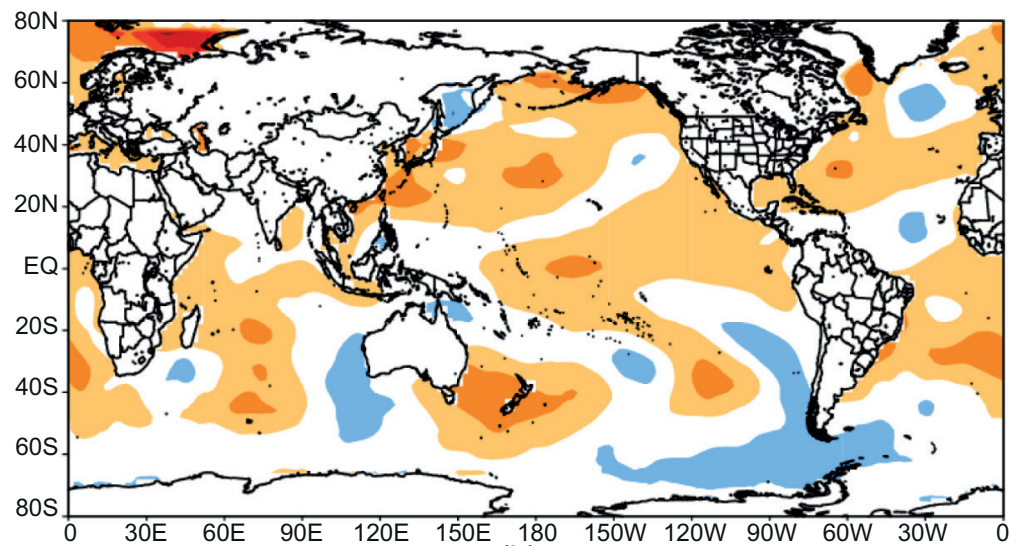

(b)

Fig. 3. SST $\left({ }^{\circ} \mathrm{C}\right)$ anomalies: (a) 2020 austral summer, and (b) 2019 austral summer. Data Source: NOAA ERSSTv5. 




(a)

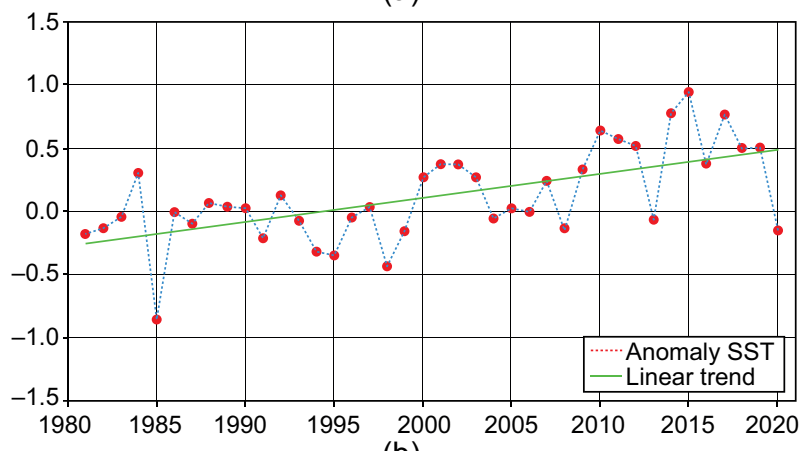

(b)

Fig. 4. (a) Correlation map between austral summer SST averaged over the subtropical South Atlantic $\left(30^{\circ}-60^{\circ} \mathrm{W}\right.$, $\left.20^{\circ}-45^{\circ} \mathrm{S}\right)$ and precipitation (1981-2020), detrended, with statistical significance level for $\mathrm{p}=0.90$ (Student's t-test), and (b) 1981-2020 time series of anomalous SST $\left({ }^{\circ} \mathrm{C}\right.$ ) averaged over the subtropical South Atlantic (same area described above). The green line is the linear trend. Data source: Global Precipitation Climatology Project and NOAA ERSSTv5.

Also, it is positively correlated with southeastern South America, including Uruguay and northern Argentina and the Rio Grande do Sul state in Brazil (Fig. 4a). There is a positive tendency of austral summer SST over the subtropical South Atlantic, with highest values during the last years (Fig. 4b). Nonetheless, the 2020 austral summer presented an intense decrease of SST, compared to the 2019 austral summer. There were positive SST anomalies over the tropical South Atlantic and in a band near $60^{\circ} \mathrm{S}$. However, there were negative SST anomalies near SEB and Argentina (Fig. 3). According to previous studies, the negative SST anomalies over tropical South Atlantic (near SEB) influence the intensification of SACZ, the increase of cyclogenesis in the ocean near SEB, and the migration of extratropical cyclones northward (Doyle and Barros, 2002; Bombardi et al., 2014a, b; Jorgetti et al., 2014). Although some of these studies found the same signal of the subtropic region in tropical South Atlantic SST, opposite results were found here.

The anomalous high-level divergence was present over the tropical Indian Ocean (approximately $0^{\circ}-50^{\circ} \mathrm{E}$ ), the western equatorial Pacific (approximately $0^{\circ}-180^{\circ} \mathrm{W}$ ), and the eastern tropical North Pacific (approximately $10^{\circ} \mathrm{N}-140^{\circ} \mathrm{W}$ ) on the summer of 2020 (Fig. 5a). These anomalous divergences were created by warmer waters over these regions (Fig. 3a) and, consequently, more convection in the underneath layer (not shown). The anomalous divergence over the Indian Ocean triggered a wave train towards the Pacific Ocean (Fig. 5b). The other two regions of anomalous divergence also triggered wave trains: the western equatorial Pacific divergence started a PSA-like wave train, while the eastern tropical North Pacific started a U-shape wave train. All these wave trains merged over southern South America in an anomalous anticyclonic circulation, which continued its path with an anomalous cyclonic circulation over the southern region of Brazil and the state of Sao Paulo, and an anticyclonic circulation northward, enhancing (inhibiting) convection over SEB. The SST anomalies over SEB and the coast of Argentina also contributed to this configuration.

\section{Comparison with the 2019 austral summer}

To improve the knowledge on the variability of SEB precipitation, the 2019 austral summer (dry) was compared to the 2020 austral summer (rainy). The first one displayed a signal inversion of the precipitation dipole anomaly over South America, compared with 2020 , presenting a negative anomalous precipitation over SEB and positive anomalies over southern Brazil (Fig. 6). This could suggest a lower occurrence of the SACZ. Unlike 2020, the precipitation anomaly over the state of Sao Paulo in the summer of 2019 was similar to the rest of SEB. 

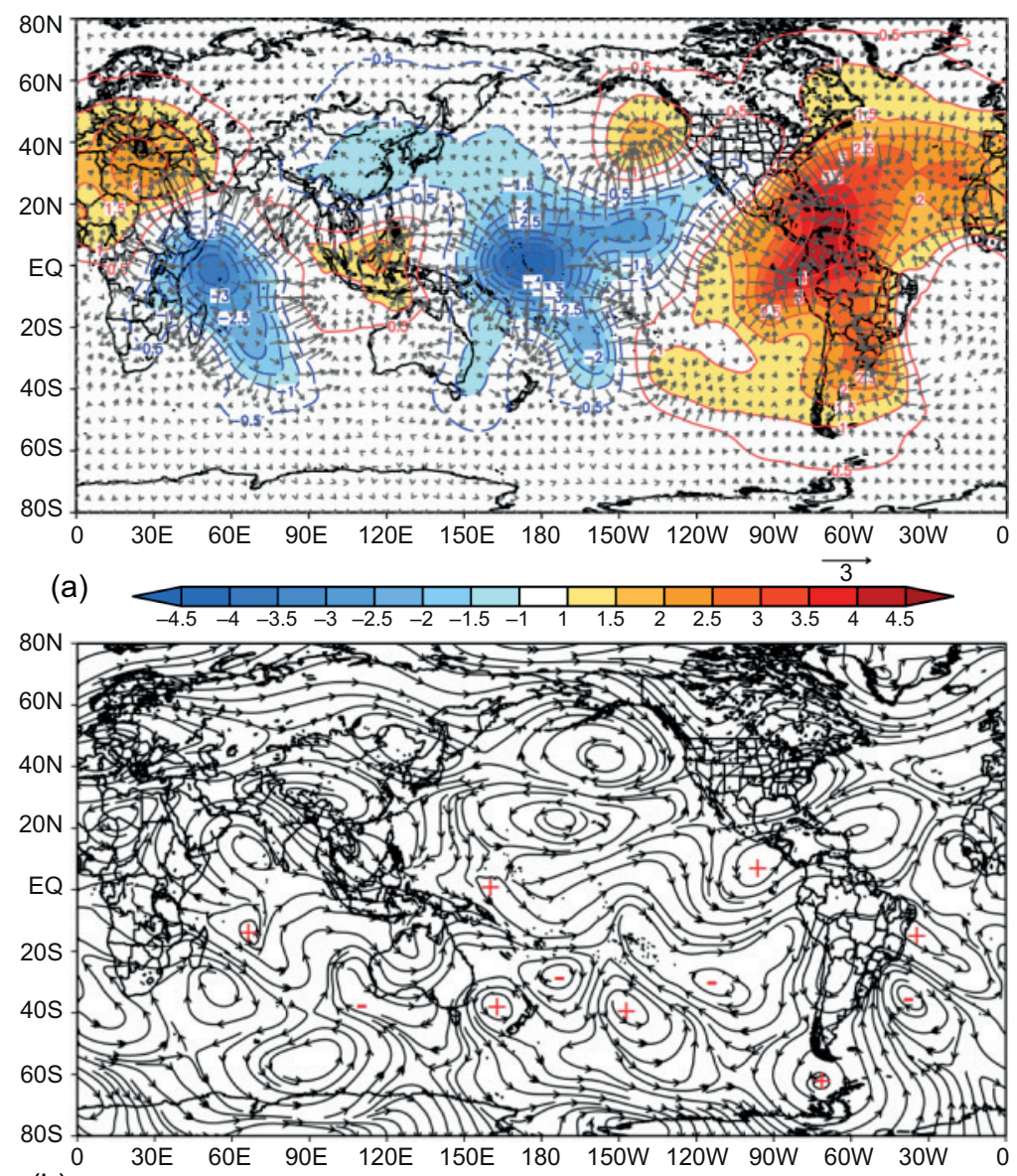

(b)

Fig. 5. Austral summer of 2020: (a) velocity potential anomalies $\left(10^{6} \mathrm{~m}^{2} \mathrm{~s}^{-1}\right.$ [contours and colors]) and divergent wind anomalies ( $\mathrm{m} \mathrm{s}^{-1}$ [vectors]) at $200 \mathrm{hPa}$, and (b) wind streamlines anomalies at $200 \mathrm{hPa}$. Red $+(-)$ signs show anticlockwise (clockwise) circulations associated with wave trains. Data source: ERA5.

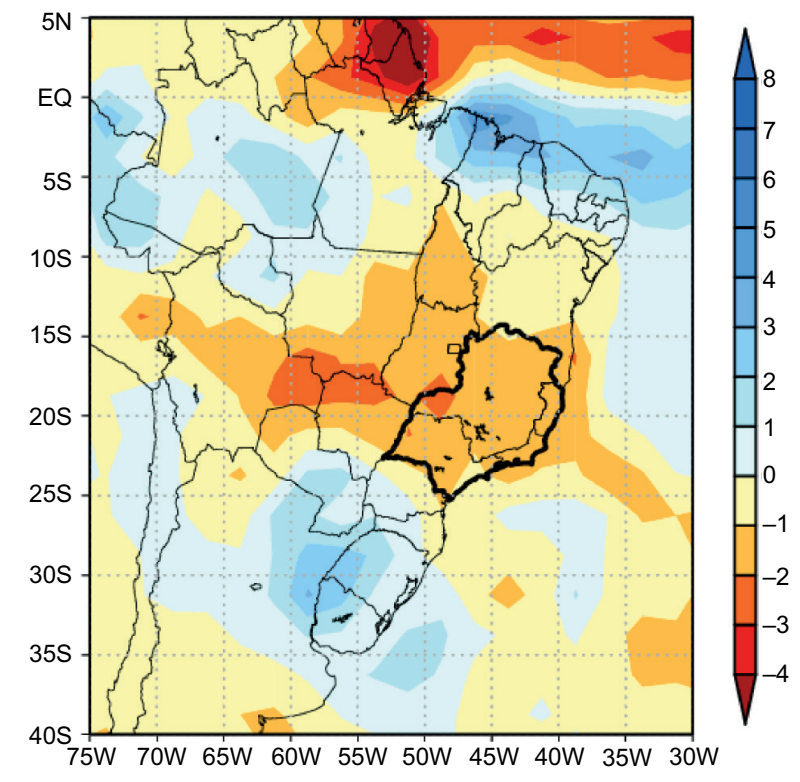

Fig. 6. 2019 austral summer precipitation anomalies (mm day $^{-1}$ ) relative to the period 1981-2020). Data source: Global Precipitation Climatology Project. 
This non-uniformity of precipitation patterns within SEB between 2019 and 2020 ratifies the difficulty of understanding climatic variability over this region.

Unlike the 2020 austral summer, the SAM pattern was not well defined in the summer of 2019 (Fig. 2b). The SAM index showed a neutral phase $(0.31$ index [JFM mean]). There were warm waters over all the equatorial Pacific (Fig. 3b). The ONI confirms the occurrence of El Niño on that summer (Table II). The tropical South Atlantic Ocean presented positive SST anomalies, similar to 2020. However, these anomalies extended southwards, reaching SEB, southern Brazil and the coast of Argentina. Besides, there was a region of negative SST anomalies near $60^{\circ} \mathrm{S}$ (Fig. 3b). The subtropical and extratropical South Atlantic presented an opposite configuration to the 2020 austral summer (Fig. 3a).

As in 2020, there was an anomalous high-level divergence at the western equatorial Pacific in 2019 (Fig. 7a). The eastern tropical North Pacific also presented an anomalous divergence (approximately $20{ }^{\circ} \mathrm{N}$, $140^{\circ} \mathrm{W}$ ) northward, stronger than in 2020 (Fig. 7a). These anomalies also triggered two wave trains: a PSA-like wave train from the western equatorial Pacific and a U-shape wave train from the eastern tropical North Pacific passing over southern South America (Fig. 7b). However, in contrast to 2020, there was no anomalous divergence at high levels over the Indian Ocean; consequently, there was no wave train from this region to the South Pacific.

Table II. 2019 austral summer CPC/NOAA indices: Oceanic Niño Index (ONI)*, and SAM index**.

\begin{tabular}{lccc}
\hline \multicolumn{3}{c}{ Jan-Mar } \\
\hline ONI & 0.8 & \\
\hline & Jan & Fev & Mar \\
\hline SAM & 0.68 & -0.5 & 0.75 \\
\hline
\end{tabular}

*https://origin.cpc.ncep.noaa.gov/products/analysis monitoring/ensostuff/ONI_v5.php

**https://www.cpc.ncep.noaa.gov/products/precip/ Cwlink/daily_ao_index/aao/monthly.aao.index.b79. current.ascii.table

Values above (below) $0.5^{\circ} \mathrm{C}\left(-0.5^{\circ} \mathrm{C}\right)$ are given in red (blue).
Therefore, circulation over South America and the Atlantic Ocean in the 2019 austral summer was different from 2020. The U-shape and PSA-like wave trains over the Pacific merged in an anomalous anticyclonic circulation over the southeastern Pacific, near the South American coast. The continuation of this wave train downstream, over the continent, generated an anomalous anticyclonic circulation over the southern region of Brazil and a cyclonic one northward, an inversion of the 2020 configuration. The SST anomalies over SEB and the coast of Argentina also contributed to this configuration. These results inhibited (enhanced) the convection over SEB during the 2019 austral summer. A U-shape wave train was also found by Coelho et al. (2016b) associated with the 2014 summer drought over SEB. Thus, the main conclusion from this comparative analysis is the distinct South American climatic patterns for two El Niño conditions.

\section{Summary and conclusions}

The predictability of climate precipitation in SEB has proven to be difficult to understand due to the unclear impact of climate variability modes on large-scale circulations that influence precipitation variability over this region (Koster et al., 2000; Nobre et al., 2006). Therefore, a better knowledge of the causes of precipitation variability might provide the basis for increasing predictability, mainly during summers.

SEB has been experiencing dry summers in the last years, including the severe 2014 drought (Coelho et al., 2016a, b). However, the 2020 austral summer in this region was unusually rainy, being the wettest summer in almost 20 years. Positive precipitation anomalies reached almost all SEB, with the exception of the state of Sao Paulo, ratifying that variability impacts are not similar in all SEB. These positive anomalies extended to the Atlantic Ocean, in a NWSE direction, indicating a greater role of SACZ. The state of Sao Paulo had a similar behavior than the southern region of Brazil, i.e., negative precipitation anomalies. These two regions displayed a dipole pattern of precipitation anomalies, which have been reported by previous works (e.g., Cunningham and Cavalcanti, 2006; Vasconcellos and Cavalcanti, 2010; Jorgetti et al., 2014; Bernardino et al., 2018; Silva et al., 2020). 


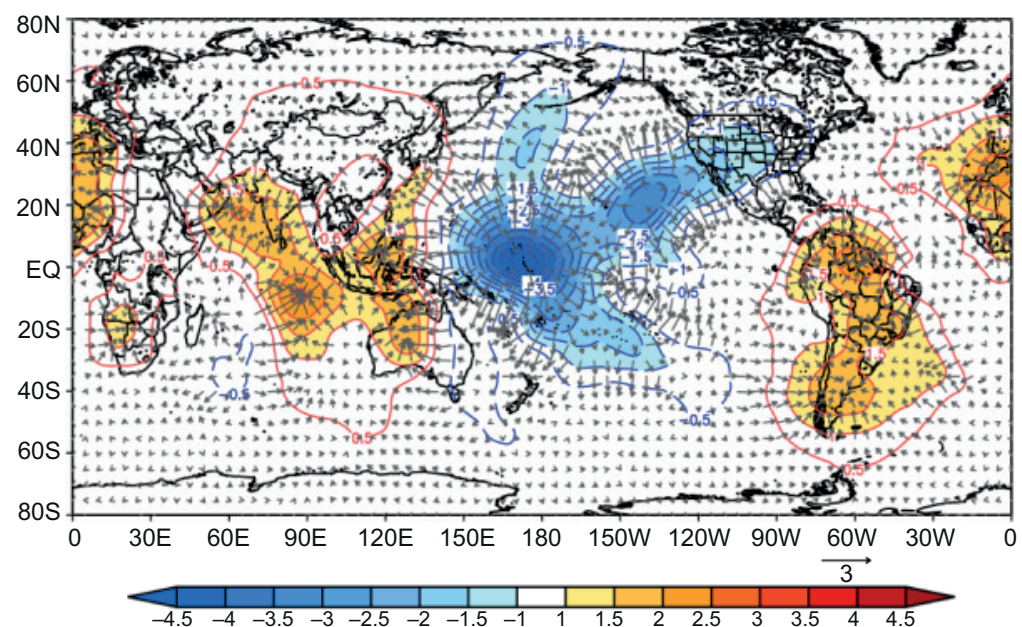

(a)



(b)

Fig. 7. 2019 austral summer: (a) velocity potential anomalies $\left(10^{6} \mathrm{~m}^{2} \mathrm{~s}^{-1}\right.$ [contours and colors]) and divergent wind anomalies ( $\mathrm{m} \mathrm{s}^{-1}$ [vectors]) at $200 \mathrm{hPa}$, and (b) wind streamlines anomalies at $200 \mathrm{hPa}$. Red + (-) signs show anticlockwise (clockwise) circulations associated with wave trains. Data source: ERA5.

Precipitation anomalies over SEB in the 2020 austral summer were influenced by different mechanisms. The SAM pattern was in a positive phase, which according to Vasconcellos and Cavalcanti (2010), Rosso et al. (2018), and Vasconcellos et al. (2019) could lead to wetter summers in some parts of SEB. The ENSO pattern was positive (E1 Niño). The 2020 austral summer also presented negative SST anomalies over the South Atlantic near SEB and Argentina. Previous studies indicated that negative SST over the SEB coast lead to an increase in precipitation over SEB during the rainy season (Doyle and Barros, 2002; Bombardi, et al., 2014a, b; Jorgetti et al., 2014).

A high level anomalous divergence over the Indian Ocean triggered a wave train to the Pacific Ocean.
Two other wave trains, originated from the western equatorial Pacific and eastern north tropical Pacific, also contributed to an anomalous anticyclonic circulation southward South America, which continued its path with an anomalous cyclonic circulation over the southern region of Brazil and the state of Sao Paulo, and an anomalous anticyclonic circulation northward, enhancing (inhibiting) convection over SEB. The South Atlantic SST anomalies and the positive SAM phase contributed to this configuration over the continent.

A comparison between the austral summers of 2020 (rainy in the SEB) and 2019 (dry in the SEB) revealed an opposition of the precipitation anomaly dipole between SEB and southern Brazil. As in 2020, there was an El Niño event in the 2019 austral summer. The 
SAM pattern was not well configurated in 2019. The subtropical and extratropical South Atlantic presented positive SST anomalies over SEB, southern Brazil and the coast of Argentina in the 2019 summer, in opposition to the 2020 summer. There was no anomalous divergence at high levels over the Indian Ocean, in consequence, there was no wave train from this region to the Pacific in the 2019 austral summer, in contrast to 2020. The U-shape and PSA-like wave trains over the Pacific were also present in the 2019 austral summer; however, they merged into an anomalous anticyclonic circulation over the southeastern Pacific, near the South American coast. Therefore, this combined wave train and the warmer South Atlantic SST contributed to an anticyclonic anomalous circulation over the southern region of Brazil and a cyclonic one northward, an opposite configuration than in 2020.

Thus, this study presents a comparative analysis of two distinct South American climatic patterns for two El Niño conditions (austral summers of 2019 and 2020). The occurrence of negative SST near SEB, the positive SAM phase, and a wave train starting over the Indian Ocean were proven to be very important to change the dry pattern observed in the 2019 summer over this region. Enhancing the knowledge on the climate variability of SEB and its mechanisms has a great potential for several socioeconomic sectors, as a guide to better managing the risks of climate variability by developing adaptation strategies to climate conditions.

\section{References}

Adler RF, Huffman GJ, Chang A, Ferraro R, Xie P, Janowiak J, Rudolf B, Schneider U, Curtis S, Bolvin D, Gruber A, Susskind J, Arkin P, Nelkin E. 2003. The version 2 global precipitation climatology project (GPCP) monthly precipitation analysis (1979-present). Journal of Hydrometeorology 4: 1147-1167. https:// doi.org/10.1175/1525-7541(2003)004<1147:TVGP$\mathrm{CP}>2.0 . \mathrm{CO} ; 2$

Bernardino BS, Vasconcellos FC, Nunes AMB. 2018. Impact of the equatorial Pacific and South Atlantic SST anomalies on extremes in austral summer precipitation over Grande river basin in Southeast Brazil. International Journal of Climatology 38: e131-e143. https:// doi.org/10.1002/joc.5358

Bombardi RJ, Carvalho LMV, Jones C. 2014a. Simulating the influence of the South Atlantic dipole on the South
Atlantic convergence zone during neutral ENSO. Theoretical and Applied Climatology 118: 251-269. https://doi.org/10.1007/s00704-013-1056-0

Bombardi RJ, Carvalho LMV, Jones C, Reboita MS. 2014b. Precipitation over eastern South America and the South Atlantic Sea surface temperature during neutral ENSO periods. Climate Dynamics 42: 1553-1568. https://doi.org/10.1007/s00382-013-1832-7

Carvalho LMV, Jones C, Liebmann, B. 2004. The South Atlantic convergence zone: Intensity, form, persistence, and relationships with intraseasonal to interannual activity and extreme rainfall. Journal of Climate 17: 88-108. https://doi.org/10.1175/1520-0442(2004)017<0088:TSACZI $>2.0 . \mathrm{CO} ; 2$

Carvalho LMV, Jones C, Ambrizzi T. 2005. Opposite phases of the antarctic oscillation and relationships with intraseasonal to interannual activity the tropics during the austral summer. Journal of Climate 18: 702718. https://doi.org/10.1175/JCLI-3284.1

Cavalcanti IFA, Ambrizzi T. 2009. Teleconexões e influências no Brasil. In: Tempo e clima no Brasil (Cavalcanti IFA, Ferreira NJ, Silva MGAJ, Dias MAFS, Eds.). Oficina de textos, São Paulo, 463 pp.

Coelho CAS, Oliveira CP, Ambrizzi T, Reboita MS, Carpenedo CB, Campos JLPS, Tomaziello ACN, Pampuch LA, Custódio MS, Dutra LMM, Da Rocha RP, Rehbein A. 2016a. The 2014 southeast Brazil austral summer drought: Regional scale mechanisms and teleconnections. Climate Dynamics 46: 3737-3752. https://doi. org/10.1007/s00382-015-2800-1

Coelho CAS, Cardoso DHF, Firpo MAF. 2016b. Precipitation diagnostics of an exceptionally dry event in São Paulo, Brazil. Theoretical and Applied Climatology 125: 769-784. https://doi.org/10.1007/s00704-015-1540-9

Cunningham CAC, Cavalcanti IFA. 2006. Intraseasonal modes of variability affecting the South Atlantic Convergence Zone. International Journal of Climatology 26: 1165-1180. https://doi.org/10.1002/joc.1309

Doyle ME, Barros VR. 2002. Midsummer low-level circulation and precipitation in subtropical South America and related sea surface temperature anomalies in the South Atlantic. Journal of Climate 15: 3394-3410. https:// doi.org/10.1175/1520-0442(2002)015<3394:MLL$\mathrm{CAP}>2.0 . \mathrm{CO} ; 2$

Gillett NP, Kell TD, Jones PD. 2006. Regional climate impacts of the Southern Annular Mode. Geophysical Research Letters 33: L23704. https://doi. org/10.1029/2006GL027721 
Hersbach H, Bell B, Berrisford P, Hirahara S, Horányi A, Muñoz-Sabater J, Nicolas J, Peubey C, Radu R, Schepers D, Simmons A, Soci C, Abdalla S, Abellan X, Balsamo G, Bechtold P, Biavati G, Bidlot J, Bonavita M, De Chiara G, Dahlgren P, Dee D, Diamantakis M, Dragani R, Flemming J, Forbes R, Fuentes M, Geer A, Haimberger L, Healy S, Hogan RJ, Hólm E, Janisková M, Keeley S, Laloyaux P, Lopez P, Lupu C, Radnoti G, de Rosnay P, Rozum I, Vamborg F, Villaume S, Thépaut J-N. 2020. The ERA5 global reanalysis. Quarterly Journal of the Royal Meteorological Society. Accepted manuscript. https://doi.org/10.1002/qj.3803

Huang B, Thorne PW, Banzon VF, Boyer T, Chepurin G, Lawrimore JH, Menne MJ, Smith TM, Vose RS, Zhang H. 2017. Extended reconstructed sea surface temperature, version 5 (ERSSTv5): Upgrades, validations, and intercomparisons. Journal of Climate 30: 8179-8205. https://doi.org/10.1175/JCLI-D-16-0836.1

IBGE. 2011. Sinopse do censo demográfico: 2010. Instituto Brasileiro de Geografia e Estatística, Rio de Janeiro. Available at: https://biblioteca.ibge.gov.br/index.php/ biblioteca-catalogo ?view $=$ detalhes $\& i d=249230$

IPEA. 2020. Ipeadata regional. Institute for Applied Economic Research. Available at: http://www.ipeadata. gov.br/Default.aspx (accessed on May 1, 2020).

Jorgetti T, Silva Dias PL, Freitas ED. 2014. The relationship between South Atlantic SST and SACZ intensity and positioning. Climate Dynamics 42: 3077-3086. https://doi.org/10.1007/s00382-013-1998-z

Koster R, Suarez M, Heister M. 2000. Variance and predictability of precipitation at seasonal-to-interannual timescales. Journal of Hydrometeorology 1: 26-46. https://doi.org/10.1175/1525-7541(2000)001<0026: VAPOPA $>2.0 . \mathrm{CO} ; 2$

Liebmann B, Allured D. 2005. Daily precipitation grids for South America. Bulletin of the American Meteorological Society 86: 1567-1570. https://doi.org/10.1175/ BAMS-86-11-1567

Muza MN, Carvalho LM, Jones C, Liebmann B. 2009. Intraseasonal and interannual variability of extreme dry and wet events over southeastern South America and the subtropical Atlantic during austral summer. Journal of Climate 22: 1682-1699. https://doi.org/10.1175/ 2008JCLI2257.1

Nobre P, Marengo JA, Cavalcanti IFA, Obregon G, Barros V, Camilloni I, Campos N, Ferreira AG. 2006. Seasonal-to-decadal predictability and prediction of South American climate. Journal of Climate 19: 5988-6004. https://doi.org/10.1175/JCLI3946.1

Rosso FV, Boiaski NT, Ferraz SET, Robles TC. 2018. Influence of the Antarctic Oscillation on the South Atlantic Convergence Zone. Atmosphere 9: 431. https:// doi.org/10.3390/atmos9110431

Silva MES, Silva CB, Ambrizzi T, Drumond A, Patucci NN. 2020. South America climate during the 19702001 Pacific Decadal Oscillation phases based on different reanalysis datasets. Frontiers in Earth Science 7: 359. https://doi.org/10.3389/feart.2019.00359

Tedeschi RG, Cavalcanti IFA, Grimm AM. 2013. Influences of two types of ENSO on South American precipitation. International Journal of Climatology 33: 1382-1400. https://doi.org/10.1002/joc.3519

Tedeschi RG, Grimm AM, Cavalcanti IFA. 2016. Influence of central and east ENSO on precipitation and its extreme events in South America during austral autumn and winter. International Journal of Climatology 36 : 4797-4814. https://doi.org/10.1002/joc.4670.

Thompson DW, Wallace JM. 2000. Annular modes in the extratropical circulation. Part I: Month-to-month variability. Journal of Climate 13: 1000-1016. https:// doi.org/10.1175/1520-0442(2000)013<1000:AMIT $\mathrm{EC}>2.0 . \mathrm{CO} ; 2$

Vasconcellos FC, Cavalcanti IFA. 2010. Extreme precipitation over southeastern Brazil in the austral summer and relations with the Southern Hemisphere annular mode. Atmospheric Science Letters 11: 21-26. https:// doi.org/10.1002/asl.247

Vasconcellos FC, Pizzochero RM, Cavalcanti IFA. 2019. Month-to-Month Impacts of Southern Annular Mode Over South America climate. Anuário do Instituto de Geociências - UFRJ 42: 783-792. https://doi. org/10.11137/2019_1_783_792

Wilks DS. 2006. Statistical methods in the atmospheric sciences. Academic Press, San Diego, CA, 627 pp. (International Geophysics Series 91.) 